\title{
The Investigation and Study on the Students' Satisfaction with the Quality of College Mathematics Teaching
}

Hong Tian, Dongyan Dai, Qianhong Song, Yanfeng Li, Dong He* , Jinyan Zhang

College of Science, Heilongjiang Bayi Agriculture University, Daqing 163319, Heilongjiang, China

DOI: $\underline{10.36347 / \text { sipms.2020.v07i05.003 }}$

| Received: 11.05.2020 | Accepted: 18.05.2020 | Published: 19.05.2020

*Corresponding author: Dong He

Abstract

Review Article

Based on the theory of customer satisfaction, this paper constructs the index system of students' satisfaction of university mathematics teaching quality, and constructs and issues the final questionnaire from five dimensions of teachers, personnel training, classroom effect, teaching management and teaching effect. Using exploratory factor analysis, comprehensive linear weighting method and satisfaction index model to calculate and analyze the survey data, and finally get the discussion about the students' satisfaction, and make a significant analysis on the influencing factors of the students' satisfaction index. Finally, combined with the results of data analysis, the methods and suggestions to improve students' satisfaction are given.

Keywords: college Mathematics Teaching;satisfaction index; exploratory factor analysis; significance test; comprehensive linear weighting.

Copyright @ 2020: This is an open-access article distributed under the terms of the Creative Commons Attribution license which permits unrestricted use, distribution, and reproduction in any medium for non-commercial use (NonCommercial, or CC-BY-NC) provided the original author and source are credited.

\section{INTRODUCTION}

In the 1960s, based on the research of customer satisfaction, the concept of student satisfaction was put forward. In essence, student satisfaction is a kind of customer satisfaction, which is a term, produced after the introduction of customer satisfaction into higher education institutions. Compared with customer satisfaction, the level of student satisfaction refers to the feeling state formed by comparing the actual perceived quality of college education service with the expected value of college.

The theory of customer satisfaction has penetrated into the field of higher education earlier abroad. No matter in the definition of the connotation of student satisfaction, the construction and use of the model and index system, they have been repeatedly tested and used, and now they have become a more mature system. Laurie Schreiner and Stephanie J uillerant 1993 designed SSI to measure the expectation and satisfaction of students in all aspects of school. It is a more authoritative measurement standard in the United States. Tracking survey is adopted almost once a year. After the survey, a national report is formed and published in Education publications or magazines. The Institute of education of Indiana University in the United States focuses on measuring aspects of university life every year. This kind of analytical research report has a large scale, wide coverage and great influence in American universities. The first survey on the satisfaction of university students was carried out in 1999 and developed to 2005 in the UK. The survey on the satisfaction of graduates has been carried out every year. In 2006, 157000 students participated in the British college students' satisfaction assessment, with a large number and a wide range of students.

The empirical research of student satisfaction evaluation in China began in 2001. The research objects are relatively unified. For college students, master's students or graduates, the focus of the research is mainly on the construction of the model and index system of student satisfaction, the factors affecting student satisfaction, the overall satisfaction of the students who provide services in a certain college or region, the satisfaction of teachers' teaching or courses, the learning experience or living environment of students The satisfaction of. With the coming of the popularization of higher education in China, the theory of customer satisfaction has been paid more and more attention by the scholars in the field of higher education and has been applied to this field. Compared with the research on the satisfaction of foreign college students, it pays more attention to the attraction of colleges and universities, the development of students' abilities, the 
evaluation of higher education services or the overall colleges and universities, and the overall objectivity.

The evaluation method of student satisfaction is the application of customer satisfaction evaluation method in the field of education. The subjective evaluation of students on the evaluation object is quantified by numbers. Likert scale is often used to evaluate student satisfaction, which is easy to operate, convenient for later data analysis, and has good effect. In order to understand the situation of the undergraduate students' satisfaction with the college mathematics teaching quality compared with the students' expectation. This paper uses Likert scale to measure the students' satisfaction. Through the quantitative evaluation and the analysis of the students' satisfaction with the overall and various indicators of the university mathematics teaching process, we can find the problems in the university mathematics teaching process。We also can find the direction and methods to solve the problems, evaluate the effect of the teaching reform from multiple perspectives, and provide direction guidance for the teaching reform, so as to effectively improve the satisfaction of the university mathematics teaching in our university High teaching quality and Realization of teaching objectives.

\section{DESIGN RESEARCH}

The survey object is undergraduates from B University. The questionnaire survey started in 2017 and has been carried out for 3 consecutive years. In order to ensure the validity and reliability of the questionnaire, 100 pre questionnaires were carried out before the formal issuance of the questionnaire. According to the feedback results, some indicators and their expressions were modified to form a formal questionnaire.

\section{INDEX SYSTEM}

College Mathematics elements mainly include: teachers, students, teaching objectives, teaching content, teaching methods, teaching conditions, etc. Through the reliability and validity analysis, on the basis of the previous index system, the questions with poor differentiation in the questionnaire were modified or deleted, and finally a satisfaction index system including 5 first level indexes and 38 second level indexes was formed, as shown in Table 1.

Table-1: Satisfaction Index System

\begin{tabular}{|c|c|c|}
\hline First level indicators & Second level indicators & Third level indicators \\
\hline \multirow{32}{*}{$\begin{array}{l}\text { Satisfaction index } \\
\text { system of } \\
\text { College Mathematics } \\
\text { Curriculum }\end{array}$} & \multirow[t]{9}{*}{ teaching staff $\mathrm{B} 1$} & Professional ethics C11 \\
\hline & & Discipline expertise $\mathrm{C} 12$ \\
\hline & & Manners C13 \\
\hline & & Teaching level C14 \\
\hline & & Work enthusiasm C15 \\
\hline & & Teaching content $\mathrm{C} 16$ \\
\hline & & Teaching responsibility $\mathrm{C} 17$ \\
\hline & & Coaching and answering $\mathrm{C} 18$ \\
\hline & & Teaching methods C19 \\
\hline & \multirow[t]{8}{*}{ personnel training $\mathrm{B} 2$} & Improvement of practical operation abilityC21 \\
\hline & & Guide students to treat learning correctly C22 \\
\hline & & Mobilize students' enthusiasm and initiative in learning C23 \\
\hline & & The improvement of theoretical learning ability C24 \\
\hline & & Lay a foundation for the development of students C25 \\
\hline & & Cultivate positive life values $\mathrm{C} 26$ \\
\hline & & Understand extracurricular knowledge C27 \\
\hline & & Teachers treat every student fairly in class C28 \\
\hline & \multirow[t]{9}{*}{ Classroom effect $\mathrm{B} 3$} & Forward looking course content C31 \\
\hline & & Communicate with students in and out of class C32 \\
\hline & & Classroom teaching atmosphere C33 \\
\hline & & The choice of Teachers C34 \\
\hline & & Course teaching progress $\mathrm{C} 35$ \\
\hline & & Degree of integration with practice C 36 \\
\hline & & $\begin{array}{l}\text { Class hours setting of theory course and experiment course } \\
\text { C37 }\end{array}$ \\
\hline & & Language expression C38 \\
\hline & & Time allocation in classroom teaching C39 \\
\hline & \multirow[t]{5}{*}{ Teaching resources B4 } & $\begin{array}{l}\text { Other supplementary teaching materials } \\
\text { C41 }\end{array}$ \\
\hline & & Infrastructure conditions of teaching laboratory $\mathrm{C} 42$ \\
\hline & & Teaching material C43 \\
\hline & & Openness of network resources $\mathrm{C} 44$ \\
\hline & & $\begin{array}{l}\text { Communication channels of teaching management } \\
\text { information } \mathrm{C} 45\end{array}$ \\
\hline & & \\
\hline
\end{tabular}




\begin{tabular}{|l|l|l|}
\hline \multirow{4}{*}{} & Teaching management B5 & The way to learn the curriculum of failing to pass C51 \\
& & The way to re-establish the existing failing courses C52 \\
& The teacher gives the score Fair C53 \\
& Course selection system C54 \\
& Students can contact teachers in time C55 \\
& Classroom management of Teachers C56 \\
& Classroom management measures C57 \\
\end{tabular}

\section{Questionnaire Quality}

The questionnaire was distributed to students through the website of questionnaire star. 1675 questionnaires were collected, 1675 valid questionnaires were collected, and the effective recovery rate was $100 \%$. The questionnaire uses Likert scale, a 5-level sequential scale, "very satisfied", "satisfied", "basically satisfied", "dissatisfied" and "very satisfied" five options, which are recorded as 5, 4, 3, 2, 1 respectively. The higher the score, the higher the satisfaction. The main indicators of questionnaire quality testing are reliability, validity and differentiation.

Reliability is a measure of the reliability of the questionnaire.It is generally believed that the reliability coefficient of colonbach is $0.60-0.70$ (the minimum acceptable value), $0.70-0.80$ (quite good), 0.80-0.90 (very good).The reliability of this questionnaire is very high. The reliability of the five secondary indicators is shown in Table 2.The indicators in the scale have high internal consistency and pass the test of reliability.

Table-2: Colonbach Reliability Coefficient of Each Secondary Index

\begin{tabular}{|l|c|c|}
\hline \multicolumn{1}{|c|}{ Second level indicators } & Number of indicators & Cronbach's Alpha $\alpha$ \\
\hline Teaching staff B1 & 7 & 0.967 \\
\hline Personnel training B2 & 8 & 0.980 \\
\hline Classroom effect B3 & 9 & 0.973 \\
\hline Teaching resources B4 & 5 & 0.950 \\
\hline Teaching management B5 & 7 & 0.959 \\
\hline
\end{tabular}

The discrimination degree mainly tests whether each item can identify the reaction degree of the subjects. The critical ratio value $C R$ value method was used for the discrimination test, and the scores of each item were arranged in the order from high to low. The first $27 \%$ of the scores were high group, and the last $27 \%$ were low group. The independent sample t test was used to test the differences between the high score and low score groups of each item. The results show that the CR value of each item is less than the significance level of 0.05 , indicating that each measure can distinguish the response degree of different subjects.

Validity is an index to measure the validity of a measurement item. It refers to the degree to which a measurement tool or means can accurately measure the things to be measured. Using KMO and Bartlett to test the correlation between measure terms. The kmo value of the questionnaire validity analysis is 0.989 , which is more than 0.8 .The validity of the questionnaire is good.

\section{Evaluation and Analysis of students' satisfaction Descriptive analysis of the questionnaire}

In terms of sample composition, 1675 samples came from 8 majors, including 762 boys and 913 girls, basically consistent with the gender ratio of the school. From the perspective of student source, the proportion of rural students is $51.3 \%$, and that of urban students is $48.7 \%$. The proportion of rural students is higher than that of urban students. In terms of grade structure, there are 38 freshmen, 204 sophomores, 538 juniors and 895 seniors. Their distribution is shown in the figure.

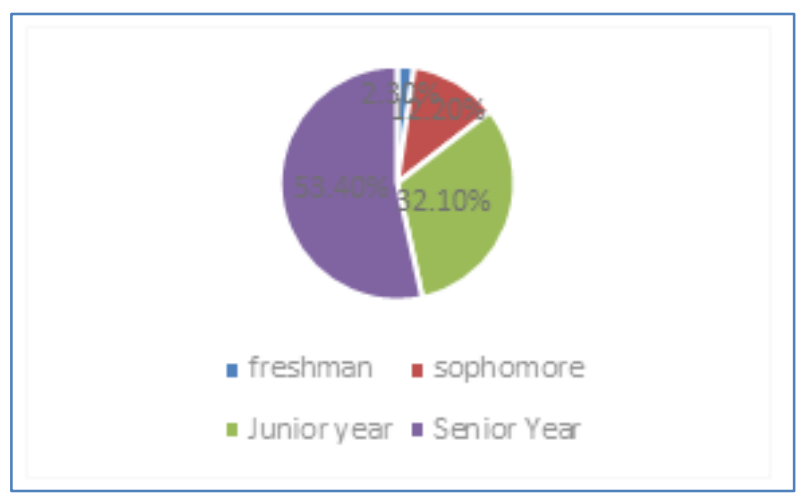

Fig-1: Distribution of School Grade

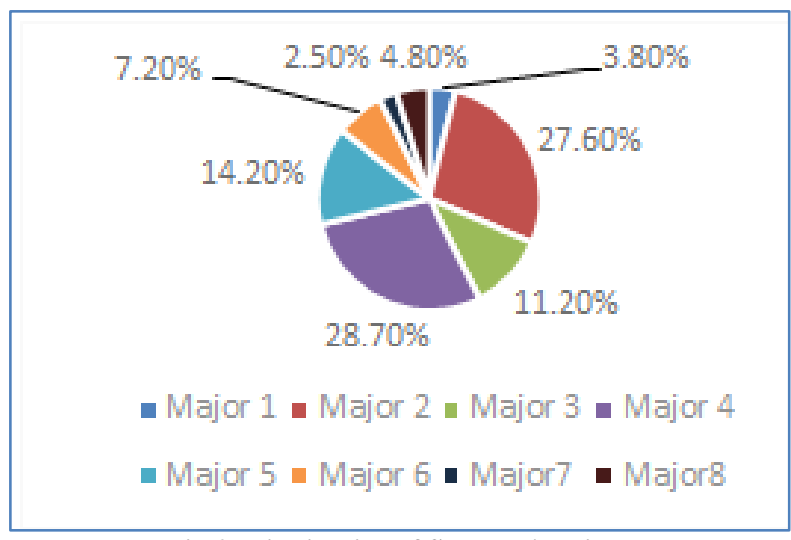

Fig-2: Distribution of Students' majors 


\begin{tabular}{|l|l|c|c|}
\hline \multicolumn{2}{|l}{ Table-3: Sample Composition of Questionnaire } \\
\hline \multirow{3}{*}{ variable } & attribute & Number of people (person) & Percentage (\%) \\
\hline \multirow{3}{*}{ grade } & male & 762 & 45.5 \\
\cline { 2 - 4 } & female & 913 & 54.5 \\
\hline \multirow{5}{*}{ Source of students } & freshman & 38 & 2.3 \\
\cline { 2 - 4 } & sophomore & 204 & 12.2 \\
\cline { 2 - 4 } & Junior year & 538 & 32.1 \\
\cline { 2 - 4 } & Senior Year & 895 & 53.4 \\
\hline & rural area & 859 & 51.3 \\
\cline { 2 - 4 } & city & 816 & 48.7 \\
\hline \multirow{5}{*}{ Major } & Major 1 & 63 & 3.8 \\
\cline { 2 - 4 } & Major 2 & 462 & 27.6 \\
\cline { 2 - 4 } & Major 3 & 188 & 11.2 \\
\cline { 2 - 4 } & Major 4 & 481 & 28.7 \\
\cline { 2 - 4 } & Major 5 & 238 & 14.2 \\
\cline { 2 - 4 } & Major 6 & 121 & 2.2 \\
\cline { 2 - 4 } & Major7 & 42 & 4.8 \\
\cline { 2 - 4 } & Major8 & 80 & \\
\hline
\end{tabular}

The average score and variance statistics of the five secondary indicators are shown in Table 4.The results show that the scores of teachers and personnel training are high, which shows that students are satisfied with the quality of university mathematics teachers. The score of teaching resources is the lowest. This is consistent with the lack of online teaching resources in our school. Generally speaking, students are satisfied with the teaching of college mathematics.

Table-4: Average Score and Variance of Secondary Indicators

\begin{tabular}{|c|c|c|c|c|c|}
\hline & B1 & B2 & B3 & B4 & B5 \\
\hline Mean & 4.546 & 4.498 & 4.482 & 4.418 & 4.47 \\
\hline Standard deviation & 0.68628 & 0.72514 & 0.72903 & 0.78453 & 0.72819 \\
\hline
\end{tabular}

\section{Analysis of Student Satisfaction Index}

Customer satisfaction degree refers to the actual degree of comparison between the actual feeling value of students' acceptance of university mathematics teaching and their expectation value. It is a quantitative statistical index of satisfaction degree.The formula can be expressed as: $\mathrm{CSD}=$ user experience value / expectation value. The measurement of $\mathrm{CS}$ is essentially the problem of customer satisfaction (CSD).

Customer satisfaction index (CSI) is an important tool to measure customer satisfaction. This is an indicator to measure the degree of satisfaction from the perspective of students. It is the result of customer satisfaction measurement through a specific causal model.

In the evaluation of students' satisfaction, many methods can be used to calculate the satisfaction index. In this paper, the score measurement method is used to calculate the satisfaction of each three-level index, and then the objective summation method is used to weighted sum the satisfaction index of each index to obtain the overall satisfaction index CSI of students.
Finally, further analysis is made according to the satisfaction index of the two-level index.

\section{Determine Index Weight}

First, determine the weight of the second and third level indicators. The index system of student satisfaction reflects the level and characteristics of higher education service quality provided by colleges and universities, and the influence degree of each index change on the change of student satisfaction is different, and the important scale reflecting the influence degree is the weight. The objective factor analysis method is used to calculate the index weight.

SPSS is used to standardize the data, then the standardized data were analyzed by exploratory factor analysis, the main factors were extracted by principal component analysis, the rotation factor load matrix can be obtained by using the equal quantity maximum method to rotate the orthogonal matrix. A total of 5 factors were extracted and the cumulative contribution rate reached $84.77 \%$. The effect was very good. The calculation results are shown in Table 5. 
Hong Tian et al., Sch J Phys Math Stat, May, 2020; 7(5): 62-69

Table-5: Explanation of Total Variance

\begin{tabular}{|c|c|c|c|c|c|}
\hline \multicolumn{3}{|c|}{ Initial eigenvalue } & \multicolumn{3}{c|}{ Sum of squares of rotating loads } \\
\hline Total & Variance percentage & Cumulative\% & Total & Variance percentage & Cumulative\% \\
\hline 29.067 & 76.492 & 76.492 & 6.749 & 17.76 & 17.76 \\
\hline 1.394 & 3.667 & 80.159 & 6.537 & 17.201 & 34.961 \\
\hline 0.75 & 1.975 & 82.134 & 6.479 & 17.051 & 52.012 \\
\hline 0.547 & 1.439 & 83.573 & 6.404 & 16.852 & 68.864 \\
\hline 0.456 & 1.201 & 84.774 & 6.046 & 15.91 & 84.774 \\
\hline
\end{tabular}

From table 8, 38 indexes have higher factor load (greater than 0.787 ) on a corresponding factor. Through factor analysis, five factors can be obtained, and the corresponding sub variables have no difference, which also proves that the questionnaire has good structural validity. The matrix of factor score coefficient obtained by calculation is shown in Table 6 .

Table-6: Factor Score Coefficient Matrix

\begin{tabular}{|c|c|c|c|c|c|c|c|c|c|c|c|}
\hline $\begin{array}{l}\text { Third level } \\
\text { indicators }\end{array}$ & $F_{1}$ & $F_{2}$ & $F_{3}$ & $F_{4}$ & $F_{5}$ & $\begin{array}{c}\text { Third level } \\
\text { indicators }\end{array}$ & $F_{1}$ & $F_{2}$ & $F_{3}$ & $F_{4}$ & $F_{5}$ \\
\hline C11 & 0.407 & -0.09 & -0.249 & -0.03 & 0.026 & C33 & -0.155 & -0.01 & 0.354 & -0.096 & -0.028 \\
\hline C12 & 0.354 & -0.104 & -0.188 & 0.035 & -0.032 & C34 & -0.222 & -0.214 & 0.373 & -0.072 & 0.207 \\
\hline C13 & 0.295 & -0.016 & -0.159 & -0.027 & -0.027 & C35 & -0.073 & -0.049 & 0.267 & -0.072 & -0.005 \\
\hline C14 & 0.295 & -0.118 & -0.135 & 0.061 & -0.034 & C36 & -0.022 & -0.013 & 0.257 & -0.005 & -0.155 \\
\hline C15 & 0.237 & -0.06 & -0.039 & -0.021 & -0.052 & C37 & -0.108 & -0.034 & 0.28 & 0.018 & -0.091 \\
\hline C16 & 0.24 & -0.031 & -0.098 & 0.006 & -0.051 & C38 & 0.038 & -0.07 & 0.197 & -0.061 & -0.038 \\
\hline C17 & 0.171 & -0.039 & 0.049 & -0.062 & -0.055 & C39 & -0.026 & -0.107 & 0.228 & -0.08 & 0.053 \\
\hline C18 & 0.158 & -0.144 & 0.086 & -0.003 & -0.033 & C41 & -0.017 & -0.143 & -0.076 & 0.448 & -0.141 \\
\hline C19 & 0.171 & -0.154 & 0.004 & 0.034 & 0.013 & C42 & -0.002 & -0.118 & -0.114 & 0.458 & -0.155 \\
\hline C21 & -0.14 & 0.364 & 0.005 & 0.006 & -0.174 & C43 & 0.153 & -0.128 & -0.219 & 0.5 & -0.238 \\
\hline C22 & -0.032 & 0.352 & -0.057 & -0.027 & -0.175 & C44 & -0.051 & -0.166 & -0.107 & 0.379 & 0.018 \\
\hline C23 & -0.115 & 0.35 & 0.027 & -0.005 & -0.195 & C45 & -0.11 & -0.019 & 0.013 & 0.102 & 0.088 \\
\hline C24 & -0.036 & 0.296 & -0.078 & -0.067 & -0.05 & C51 & -0.095 & -0.48 & -0.104 & -0.149 & 0.913 \\
\hline C25 & -0.061 & 0.31 & -0.024 & -0.004 & -0.158 & C52 & 0.028 & 0.083 & -0.187 & -0.184 & 0.331 \\
\hline C26 & 0.012 & 0.311 & -0.099 & -0.043 & -0.119 & C53 & 0.053 & 0.1 & -0.265 & -0.108 & 0.289 \\
\hline C27 & -0.168 & 0.318 & 0.047 & 0.031 & -0.167 & C54 & -0.187 & -0.148 & 0.067 & 0.077 & 0.267 \\
\hline C28 & 0.031 & 0.13 & -0.104 & -0.1 & 0.111 & C55 & -0.104 & 0.129 & -0.046 & -0.148 & 0.238 \\
\hline C31 & -0.171 & -0.043 & 0.356 & 0.017 & -0.091 & C56 & -0.015 & 0.101 & -0.115 & -0.093 & 0.193 \\
\hline C32 & -0.122 & -0.045 & 0.35 & -0.103 & -0.016 & C57 & -0.068 & 0.004 & -0.031 & 0.011 & 0.158 \\
\hline
\end{tabular}

According to table 6 , the factor score equation is obtained $\quad F_{l}=\beta_{1 l} x_{1}+\beta_{2 l} x_{2}+\cdots+\beta_{n l} x_{n}$

In Equation (1), $F_{l}$ is the Score for factor $l, l=1,2,3,4,5$, and $x_{i}$ is the index value $n=38, \beta_{k l}$ is the coefficient of index.

$$
e_{l}=\frac{\lambda_{l}}{\sum_{l=1}^{m} \lambda_{l}},
$$

In formula (2), $\lambda_{l}$ is the eigenvalue of factor $l$.

$p_{k}$ is the importance of the $\mathrm{k}-\mathrm{th}$ indicator,

$$
p_{k}=\left|\sum_{l=1}^{m} \beta_{k l} * e_{l}\right|, \quad k=1,2, \cdots, 38
$$


Calculate the importance of each item index $p_{k}$. Renumber each item index according to the index systemthen and convert $p_{k}$ to $p_{i j}$.

The weight of the indicator is $w_{i j}$

$$
w_{i j}=p_{i j} / \sum_{j=1}^{n_{j}} p_{i j}, j=1,2,3,4,5
$$

In formula (4), $n_{j}$ is the number of indicators included in the second level indicator $j$. Table 7 shows the calculation results of the third level index importance and weight.

Table-7: Average score,Importance and Weight of The Third Level Indicators

\begin{tabular}{|c|c|c|c|c|c|c|c|c|c|c|c|c|c|}
\hline $\begin{array}{c}\text { The Third } \\
\text { Level Indicators }\end{array}$ & C11 & $\mathrm{C} 12$ & C13 & C14 & C15 & C16 & $\mathrm{C} 17$ & C18 & C19 & C21 & $\mathrm{C22}$ & $\mathrm{C} 23$ & $\mathrm{C24}$ \\
\hline Importance $p_{i j}$ & 0.357 & 0.311 & 0.261 & 0.258 & 0.209 & 0.212 & 0.152 & 0.138 & 0.148 & 0.113 & 0.018 & 0.091 & 0.023 \\
\hline Average $\bar{x}_{i}$ & 4.61 & 4.54 & 4.57 & 4.54 & 4.58 & 4.53 & 4.59 & 4.52 & 4.43 & 4.47 & 4.52 & 4.47 & 4.52 \\
\hline Weight $w_{i}$ & 0.175 & 0.152 & 0.127 & 0.126 & 0.102 & 0.104 & 0.074 & 0.067 & 0.073 & 0.236 & 0.037 & 0.190 & 0.049 \\
\hline $\begin{array}{c}\text { The Third } \\
\text { Level Indicators } \\
\end{array}$ & $\mathrm{C} 25$ & $\mathrm{C} 26$ & $\mathrm{C} 27$ & $\mathrm{C} 28$ & C31 & C32 & C33 & C34 & C35 & C36 & C37 & C38 & C39 \\
\hline Importance $p_{i j}$ & 0.044 & 0.020 & 0.139 & 0.031 & 0.149 & 0.106 & 0.134 & 0.199 & 0.063 & 0.017 & 0.093 & 0.034 & 0.023 \\
\hline Average $\bar{x}_{i}$ & 4.5 & 4.53 & 4.44 & 4.53 & 4.46 & 4.48 & 4.49 & 4.42 & 4.51 & 4.47 & 4.47 & 4.54 & 4.5 \\
\hline Weight $w_{i}$ & 0.093 & 0.041 & 0.290 & 0.065 & 0.182 & 0.129 & 0.164 & 0.243 & 0.077 & 0.020 & 0.114 & 0.042 & 0.029 \\
\hline $\begin{array}{c}\text { The Third } \\
\text { Level Indicators }\end{array}$ & C41 & $\mathrm{C} 42$ & $\mathrm{C} 43$ & C44 & $\mathrm{C} 45$ & C51 & C52 & C53 & C54 & C55 & C56 & C57 & \\
\hline Importance $p_{i j}$ & 0.018 & 0.004 & 0.133 & 0.049 & 0.097 & 0.099 & 0.026 & 0.048 & 0.168 & 0.088 & 0.011 & 0.059 & \\
\hline Average $\bar{x}_{i}$ & 4.38 & 4.39 & 4.44 & 4.41 & 4.47 & 4.37 & 4.52 & 4.5 & 4.4 & 4.47 & 4.53 & 4.5 & \\
\hline Weight $w_{i}$ & 0.059 & 0.013 & 0.442 & 0.163 & 0.323 & 0.197 & 0.052 & 0.096 & 0.337 & 0.177 & 0.021 & 0.119 & \\
\hline
\end{tabular}

Sum each third level index to get the corresponding second level index importance $D_{k}(k=1,2, \cdots, 5)$.Total importance of the system to be evaluated

$$
D=\sum_{k=1}^{5} D_{k}
$$

For the evaluation system of multi-layer structure, according to the principle of additivity, calculate secondary index weight $A_{j}$.

$$
A_{k}=D_{k} / D
$$

According to formula (5) and (6), average score, importance and weight of the secend level indicators are calculated as shown in the table 8.

Table-8: Average score,Importance and Weight of The Secend Level Indicators

\begin{tabular}{|c|c|c|c|c|c|}
\hline $\begin{array}{c}\text { The Secend } \\
\text { Level Indicators }\end{array}$ & B1 & B2 & B3 & B4 & B5 \\
\hline Average $\bar{Y}_{j}$ & 4.546 & 4.498 & 4.482 & 4.418 & 4.47 \\
\hline Importance $D_{k}$ & 2.047 & 0.479 & 3.752 & 2.471 & 3.115 \\
\hline Weight $A_{j}$ & 0.494 & 0.115 & 0.198 & 0.072 & 0.121 \\
\hline
\end{tabular}




\section{Analysis of Student Satisfaction Index}

Calculation formula of student satisfaction index is

$$
S C I=\frac{\sum_{j=1}^{m} \bar{Y}_{j} \cdot A_{j}}{5} \cdot 100 \%
$$

In formula (7), $\bar{Y}_{j}$ is the average of the secend level indicators. $A_{j}$ is Weight, $m$ is the number of the Secend level indicators, 5 is maximum satisfaction score.

$$
S C I=\frac{\sum_{i=1}^{n_{j}} \bar{X}_{i j} \cdot w_{i j}}{5} \cdot 100 \%, i=1,2, \cdots, 38, j=1,2,3,4,5
$$

In formula (8), $\bar{X}_{i j}$ is the average of the third level indicators. $w_{i j}$ is Weight, $n_{j}$ is the number of indicators, 5 is maximum satisfaction score. The satisfaction index of the secend level indicators are shown in the figure 3 .

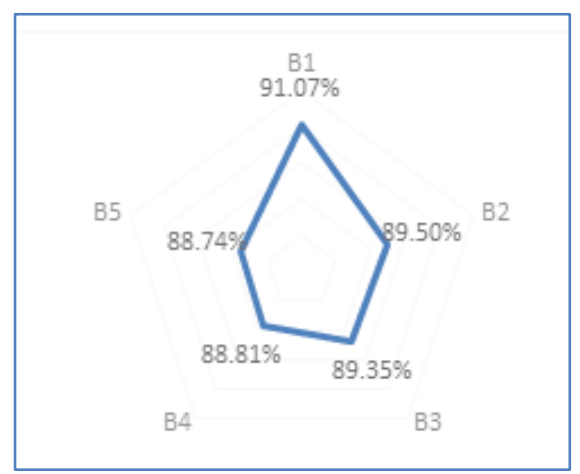

Fig-3: The Satisfaction Index of the Secend Level Indicators
It can be seen that students have the highest satisfaction index for teachers, which is the high recognition of students for the quality of school teachers. Secondly, the cultivation of talents and the effect of classroom teaching show that students are satisfied with the existing classroom teaching methods and management system of college mathematics. The satisfaction index of teaching resources and teaching management is low, which shows that in the future teaching, we should not only strengthen the teaching management, but also strengthen the construction of online and offline teaching resources.

\section{Analysis of influencing factors}

The independent sample t-test is used to test the influence of source type and gender on satisfaction index. The calculation results are shown in Table 9

Table-9: Independent sample t-test

\begin{tabular}{|l|l|l|l|}
\hline Influence factor & t & Sig. & Significance \\
\hline gender & -1.461 & 0.144 & not significant \\
\hline the type of student source & -4.533 & 0 & significant \\
\hline
\end{tabular}

The results showed that gender had no significant effect on the satisfaction index, and the type of student source had significant effect on the satisfaction index.The satisfaction of students from rural areas (average $88.72 \%$ ) was significantly lower than that from urban areas (average $91.72 \%$ ).
The results of variance analysis show that the satisfaction index of students in different majors and grades is significantly different, among which the satisfaction index of students in grade four is significantly higher than that of students in other grades.

Table-10: ANOVA (different majors)

\begin{tabular}{|c|c|c|c|c|c|}
\hline & SS & df & MS & F & P-Value \\
\hline Group & 0.678 & 3 & 0.226 & 12.348 & 0.000 \\
\hline Error & 30.591 & 1671 & 0.018 & & \\
\hline Total & 31.269 & 1674 & & & \\
\hline
\end{tabular}




\begin{tabular}{|c|c|c|c|c|c|}
\multicolumn{7}{c|}{ Table-11: ANOVA (Different grades) } \\
\hline & SS & df & MS & F & P-Value \\
\hline Group & 0.623 & 7 & 0.089 & 4.843 & 0.000 \\
\hline Error & 30.646 & 1667 & 0.018 & & \\
\hline Total & 31.269 & 1674 & & & \\
\hline
\end{tabular}

To sum up, the source of students, majors and grades have a significant impact on the student satisfaction index. When teaching, teachers should teach students according to their aptitude, combining with the students' quality and professional needs.

\section{CONCLUSIONS}

The key and importance of learning satisfaction lies in that it can be measured by scientific methods as the subjective expression of College Students' learning. The research data fully reflects the actual feelings of college students on college mathematics teaching. Through the research and analysis, the following conclusions are drawn:

(1)The students' overall satisfaction with mathematics teaching in our university is higher, the highest one is the satisfaction with teachers, and the satisfaction with teaching management and teaching resources is lower. In the future teaching, we should strengthen the improvement in the teaching management, pay attention to the construction of teaching resources, especially the construction of online resources.

(2) There are significant differences in student satisfaction index among colleges, which mainly shows that the student satisfaction index of the major of advantage discipline is higher than the graduate satisfaction index of general specialty, and there is no significant difference in the gender of student satisfaction, which is consistent with the experience judgment. However, it is worth noting that the source of students has a significant impact on the student satisfaction index. Therefore, in the future teaching, teachers should pay more attention to the characteristics of students and teach students according to their aptitude.

(3) Through the evaluation and analysis of the student satisfaction index, it is beneficial for teachers to understand their own weak links in teaching, find their own shortcomings, improve their own competitiveness, and help schools to formulate correct development strategies.
(4) Using this index system and analysis method, we can realize the historical data comparison of students' satisfaction, so as to determine whether the university mathematics work is effective and meets the needs of students, thus forming an effective interaction between the University and students. High student satisfaction will make the university have good social reputation, attract more high-quality students, more talents and funds, form the value-added of intangible assets, and realize a good cycle of school development.

\section{ACKNOWLEDGEMENT}

The preparation of this manuscript is supported by the Key topics of the 13th five year plan for education science of Heilongjiang Province in 2018: Research and Practice on the teaching reform of college mathematics basic course (GBB1318093), General research items of higher education reform in Heilongjiang Province in 2019: Building a studentcentered evaluation system of College Students' learning effectiveness (SJGY20190479).

\section{REFERENCES}

1. HJ So, TA Brush. Student perceptions of collaborati ve learning, social presence and satisfaction in a ble nded learning environment: Relationships and critic al factors [J].Computers\&Education. 2008, 30(2):8 6-104.

2. Mittal R, Sciberras E, Sewell J, Efron D. Assessme nt of children with learning and behavioural proble ms: Comparison of a multidisciplinary and sole pae diatrician model. Journal of paediatrics and child $h$ ealth. 2014 Feb;50(2):135-40.

3. MV Rez, MC Pez. Blended learning in higher educ ation: Students'perceptions andtheir relation to outc omes [J].Computers\&Education. 2011,12(7):53-76.

4. Li- Wei Mai, A Comparative Study between UK a nd US: The Student Satisfaction in Higher Educatio $\mathrm{n}$ and itsI nfluential Factors [J]. University of West minster Journal of Marketing Management; 2005.

5. Chang Y, Chang W Y. The relationship between tou rism education, learning satisfaction and learning ef fectiveness: An example of the department of touris $\mathrm{m}[\mathrm{J}]$. Journal of Interdisciplinary Mathematics. 20 $15,18(6): 869-882$. 